\title{
Use of Shared Faculty in U.S. and Canadian Dental Schools
}

\author{
Darryl T. Hamamoto, D.D.S., Ph.D.; Suzanne K. Farrar, R.D.H., M.S.H.C.M.; \\ Daniel J. Caplan, D.D.S., Ph.D.; Terrence F. Lanphier, D.D.S., M.B.A.; \\ Jeanne C. Panza, D.M.D.; André V. Ritter, D.D.S., M.S., M.B.A.
}

Abstract: Dental schools are facing substantial financial challenges and a shortage of faculty members. One solution to address these issues has been to hire "shared" faculty members, i.e., faculty members whose primary appointment is at one institution who are hired by another institution to teach a course or part of a course. This is a controversial concept. A survey of academic deans at U.S. and Canadian dental schools was conducted for this study; thirty-nine (54 percent) of the seventy-two academic deans completed the online survey. This survey found that the use of shared faculty members is not rare amongst U.S. and Canadian dental schools and that the opinions of the academic deans about the use of shared faculty members ranged widely-from strong support to strong disapproval. Using shared faculty members has advantages and disadvantages for students, the shared faculty members, and both institutions. Many of the disadvantages could be potentially minimized by stakeholders' working together to develop collaborative arrangements. Networks could be developed in which institutions coordinate hiring of shared faculty members based on what expertise is needed. Financial challenges and shortages of faculty members are unlikely to be resolved in the near future, but use of shared faculty members is one promising approach to begin to meet these challenges.

Dr. Hamamoto is Associate Dean for Advanced and Graduate Education and Associate Professor, Diagnostic and Biological Sciences, School of Dentistry, University of Minnesota; Ms. Farrar is Associate Professor, Comprehensive Dentistry and Biomaterials, School of Dentistry, Louisiana State University Health Sciences Center; Dr. Caplan is Professor and Head, Preventive and Community Dentistry, College of Dentistry, University of Iowa; Dr. Lanphier is Associate Professor, Oral and Maxillofacial Surgery, School of Dentistry, Creighton University; Dr. Panza is Associate Dean for Clinic Affairs and Associate Professor, Oral Diagnosis and Radiology, College of Dentistry, University of Oklahoma; and Dr. Ritter is Professor and Graduate Program Director, Operative Dentistry, School of Dentistry, University of North Carolina at Chapel Hill. Direct correspondence and requests for reprints to Dr. Darryl Hamamoto, Diagnostic and Biological Sciences, School of Dentistry, University of Minnesota, 7-536 Moos Tower, 515 Delaware Street, S.E., Minneapolis, MN 55455; 612-625-6951 phone; 612-624-0477 fax; hamam001@umn.edu.

Keywords: dental education, educational models, dental faculty, dental schools, faculty shortage

Submitted for publication 4/3/12; accepted 5/25/12

$\mathrm{O}$ ne of the main drivers for change in dental education is the need to address the substantial financial challenges facing dental schools. Dental education is one of the most expensive educational programs within a university. ${ }^{1-3}$ As state support for dental education continues to decrease, dental schools have increased their reliance on tuition and student fees and increased patient care services to sustain their dwindling operational budgets. ${ }^{3,4}$ The current financial challenges have resulted in decreased investments to maintain dental school facilities, decreased diversity in the dental student population, decreased faculty scholarship, and loss of full-time clinical faculty members..$^{4,5}$ Loss of dental faculty members to either private practice or retirement is one contributing factor to the shortage of dental faculty members and has been reported for many years. ${ }^{6}$ Thus, challenges due to financial pres- sures and shortage of faculty members will require innovative changes to ensure the quality of dental education in the future.

One solution to address these issues has been to hire "shared" faculty members, i.e., faculty members whose primary appointment is at one institution (the primary institution) who are hired by another institution (the secondary institution) to teach a course or part of a course. This designation typically does not include teaching continuing dental education courses, giving seminars/lectures during a one-time visit to another institution, or teaching during a sabbatical. There are many reasons for an institution to consider hiring shared faculty members, such as reducing the cost of teaching, addressing faculty shortages, enhancing student learning, and allowing faculty members to supplement their salaries, especially in light of the growing gap between academic 
and private practice income. However, the use of shared faculty members is a controversial concept. In the survey conducted for our study, one academic dean expressed the opinion that the use of shared faculty members is "a scam perpetrated by secondtier schools that can't/won't spend the resources for faculty and try to get first-tier schools to foot all of the indirect faculty costs while reaping the benefits of their best faculty. They want to share talent but not cost." In contrast, another academic dean noted, "I think that it [the use of shared faculty members] is a great idea and hope that ADEA would help us pursue this, perhaps by establishing a database of interested schools, faculty, [and] topics."

Though the use of shared faculty members may appear advantageous to the secondary institution and disadvantageous to the primary institution, it could have positive and negative effects on both institutions as well as on students and the shared faculty members themselves. Thus, students, faculty members, administrators, and other stakeholders in dental education must become engaged so that shared faculty member programs can be proactively and thoughtfully discussed and developed to benefit all constituencies. The dental education landscape is primed for this discussion, as current financial pressures and the shortage of faculty members are unlikely to be resolved in the near future. Therefore, the purposes of this position paper are to a) describe the background leading to the development of the use of shared faculty members; b) identify the prevalence and reasons for use of shared faculty members among U.S. and Canadian dental schools; c) describe the potential impact of using shared faculty members on students, shared faculty members, and the institutions; d) discuss policy implications that result from the use of shared faculty; and e) suggest the creation of collaborative networks to develop the use of shared faculty members.

We will make the case that the use of shared faculty members should be expanded because of its potential to enhance student learning, reduce the cost of dental education without decreasing the quality of the experience, and help address the shortage of dental faculty members. The concern regarding imbalance in the distribution of costs and benefits between the primary and secondary institutions can be resolved by having both institutions involved in the process from the very start. Cooperation between institutions could result in the development of networks of shared faculty members so that each institution serves as both the primary and secondary institution. Finally, further research is needed to determine the impact of using shared faculty members on student learning, the quality of work-life of shared faculty members, and impact on the financial status and scholarly productivity of both primary and secondary institutions.

\section{Background}

Dental schools are not alone in facing the financial challenges of educating students. As state support for institutions of higher education has decreased, ${ }^{7,8}$ the types of faculty members they hire has changed. Over the last forty years, there has been a national trend in higher education toward a decrease in the number of tenure/tenure-track faculty members and an increase in hiring of full- and parttime, non-tenured/non-tenure-track (i.e., contingent) faculty members. ${ }^{9,10}$ This trend of decreased hiring of tenure-track faculty members has also occurred in the health professions. ${ }^{11-13}$ More non-tenure-track faculty members are also being hired in dental schools. The percentage of dental schools that offer non-tenuretrack faculty appointments has increased from less than 40 percent in 1980 to 94 percent in $2007 .{ }^{14} \mathrm{In}$ 2007-08, over 50 percent of full-time dental faculty members were on non-tenure-track appointments. ${ }^{15}$ Thus, dental schools have followed the trend in higher education of hiring more non-tenure-track faculty members.

Hiring non-tenure-track faculty members allows for flexibility in staffing to decrease costs, increase the ability to adapt to changes in educational needs, and permit the hiring of valuable professionals who lack the credentials for tenure-track positions. ${ }^{16,17}$ Another important reason for hiring non-tenure-track faculty members in health professions schools is the shortage of faculty members. ${ }^{18}$ There are shortages of faculty members in schools of nursing, ${ }^{19,20}$ pharmacy, ${ }^{21}$ and dentistry. ${ }^{6}$ The shortage of available dental faculty members has been reported for many years. In 2007-08, there were 316 vacant full-time budgeted faculty positions in fifty-three of the fifty-six dental schools that responded to the American Dental Education Association (ADEA) annual survey. ${ }^{6}$

This movement away from hiring tenured or tenure-track faculty members has taken on a new twist. Instead of hiring non-tenure-track faculty members for part- or full-time positions, some dental schools are hiring shared faculty members - that is, 
faculty members who have appointments at other institutions. For example, A.T. Still University's Arizona School of Dentistry and Oral Health utilizes part-time adjunct faculty members to do the majority of its teaching. ${ }^{22}$ Indeed, one of the guiding principles followed in the development of that dental program was that no full-time basic science faculty members would be hired. The school's part-time basic science faculty members come from other institutions to teach.

The idea of shared faculty members is not limited to dentistry. The Oregon Consortium for Nursing Education (OCNE) has attempted to address the shortage of nursing faculty members by bringing together all of the state's nursing programs into one initiative. ${ }^{23,24}$ The member nursing programs of the OCNE share faculty members as well as development and implementation of curriculum, facilities, student services systems, and other resources. Sharing faculty members between residency training programs has been reported in medical schools, ${ }^{25}$ and sharing of faculty members across institutions has been reported in other parts of higher education. ${ }^{26}$

Some issues faced by contingent faculty members are relevant to shared faculty members. However, a major difference between contingent and shared faculty members is that shared faculty members have full-time appointments at another institution. This arrangement gives shared faculty members distinct advantages that will be discussed below.

\section{Methods}

To examine the extent of and opinions about the use of shared faculty members in U.S. and Canadian dental schools, a web-based survey was developed in SurveyMonkey for distribution to the schools' associate deans for academic affairs (or the equivalent administrative position). The survey was piloted with a small group of faculty members and then modified to its final form. Approval for use of the survey was obtained from the Institutional Review Board of the University of Iowa under exempt research status (IRB Protocol \# 201109870).

An e-mail with a link to the online survey was sent to Dr. David Brunson at ADEA, who then forwarded it to the academic deans of the sixty-two U.S. and ten Canadian dental schools. The academic deans were informed that their responses would be anonymous and were given two weeks to complete the survey. An e-mail was sent after the first week reminding them to complete the survey if they had not yet done so. Nonrespondents were not contacted further. Two weeks after the initial e-mail message, data were downloaded and analyzed.

\section{Results}

Thirty-nine (54 percent) of the seventy-two academic deans completed the online survey. Response rates were 42 percent (twenty-two of fifty-two) for public schools and 60 percent (twelve of twenty) for private schools. Five respondents did not specify their school type. All thirty-nine academic deans who completed the survey responded to questions about the use of shared faculty members whose primary appointments were at their institution. Eleven of the thirty-nine (28 percent) academic deans indicated that they knew of at least one faculty member from their school who taught at another institution, while twenty-five (64 percent) indicated that they did not know of any and three ( 8 percent) did not answer the question (Table 1). Twelve of the thirty-nine (31 percent) academic deans indicated that faculty member(s) from another institution taught in their dental schools (Table 2). Four academic deans reported that their dental school was both a primary and secondary institution for shared faculty, while seven reported that their school was a primary institution only and eight reported that their dental school was a secondary institution only.

Respondents from both primary and secondary institutions indicated that shared faculty members are more often tenured; teach basic science courses; teach only one or two courses for fewer than twenty hours each year; travel to the secondary institution to teach; and are personally compensated by the secondary institution more often than their primary institution is compensated (Tables 1 and 2). Academic deans at primary institutions reported that shared faculty members taught at the secondary institution mainly while using their consulting or vacation time. Academic deans at secondary institutions reported that most of the shared faculty members taught using a traditional didactic format.

While the survey helped us capture information about the use of shared faculty members in the responding institutions, the study has several limitations. First, the validity and reliability of the survey instrument were not evaluated. Second, the overall response rate was only 54 percent, and only one attempt to contact nonrespondents was made. 
It is possible that academic deans at dental schools who use shared faculty members were more likely to complete the survey than other academic deans. Third, a higher percentage of academic deans from private dental schools completed the survey than did academic deans from public dental schools. If decreased state support is a major driver for the use of shared faculty and private dental schools are less affected, then our estimate for the prevalence of the use of shared faculty may be low. Finally, academic deans might not know whether faculty members from their school are teaching at other institutions, whereas they are more likely to know if faculty members from other institutions are teaching at their school. Thus, our results may underestimate the number of shared faculty from primary institutions. Despite

Table 1. Survey responses about shared faculty members from academic deans at the primary institutions

Question
Does your dental school have faculty members
with primary appointments at your school who
teach a course or part of a course at a different
institution?

How many faculty members from your dental school teach a course or part of a course at a different institution?*

Which of the following best describes the status of the shared faculty member?*

What type(s) of course(s) does each shared faculty member teach at your school?*

How many contact hours per year on average does each shared faculty member teach at the secondary institution?*

Over the past five years, how many courses has the shared faculty member taught for the secondary institution?*

How has the shared faculty member taught the course or part of a course at the secondary institution?*

Whom does the other institution compensate for the shared faculty member's teaching efforts?*

When a shared faculty member is away from your school, time away is considered:*

N (type) Number

39 (schools)

Yes $=11$

$\mathrm{No}=25$

Don't know/missing=3

11 (schools)

One $=1$

$\mathrm{TwO}=4$

Three $=1$

$>$ Three $=3$

Don't know=2

27 (faculty)

Tenured $=17$

Tenure-track, not yet tenured $=0$

Non-tenure-track, contract, clinical-track, adjunct $=6$

Don't know $=4$

27 (faculty)

Basic sciences $=12$

Clinical sciences (preclinical didactic and lab courses) $=10$ Clinic (supervision of clinical care) $=3$

Don't know $=3$

27 (faculty)

$<10$ hours $=11$

$10-20$ hours $=6$

$21-30$ hours $=5$

$31-40$ hours $=1$

$>40$ hours $=0$

Don't know $=4$

27 (faculty)

One or two $=19$

Three or four $=1$ $>$ Four $=0$

Don't know $=7$

27 (faculty)

By physically traveling to the secondary institution $=18$ Via online or distance education courses $=5$

Don't know $=7$

27 (faculty)

The shared faculty member $=14$

Your institution $=2$

There is no compensation $=5$

Don't know $=6$

27 (faculty)

Vacation $=5$

Leave without pay $=2$

Consulting $=9$

Other $=2$

Don't know $=4$

*Includes only those who answered "Yes" to the first question in this table.

Note: The number of answers to a question might be greater than the $\mathrm{N}$ if more than one answer could be chosen or could be lower than the $\mathrm{N}$ if no answer was given for a faculty member. 
Table 2. Survey responses about shared faculty members from academic deans at the secondary institutions

\begin{tabular}{|c|c|c|}
\hline Question & N (type) & Number \\
\hline $\begin{array}{l}\text { Does your dental school employ shared faculty } \\
\text { members whose primary appointment is at } \\
\text { another institution? }\end{array}$ & 39 (schools) & $\begin{array}{l}\mathrm{Yes}=12 \\
\mathrm{No}=27\end{array}$ \\
\hline $\begin{array}{l}\text { How many shared faculty members from } \\
\text { another institution teach a course or part of a } \\
\text { course at your dental school?* }\end{array}$ & 12 (schools) & $\begin{array}{c}\text { One }=3 \\
\text { Two }=1 \\
\text { Three }=1 \\
>\text { Three=6 } \\
\text { Don't know }=1\end{array}$ \\
\hline $\begin{array}{l}\text { Which of the following best describes the } \\
\text { status of the shared faculty member at his/her } \\
\text { home institution?* }\end{array}$ & 29 (faculty) & $\begin{array}{c}\text { Tenured }=17 \\
\text { Tenure-track, not yet tenured=3 } \\
\text { Non-tenure-track, contract, } \\
\text { clinical-track, adjunct=4 } \\
\text { Don't know }=5\end{array}$ \\
\hline $\begin{array}{l}\text { What type(s) of course(s) does each shared } \\
\text { faculty member teach at your dental school?* }\end{array}$ & 29 (faculty) & $\begin{array}{c}\text { Basic sciences }=23 \\
\text { Clinical sciences (preclinical didactic and lab courses })=4 \\
\text { Clinic (supervision of clinical care })=2 \\
\text { Don't know }=2\end{array}$ \\
\hline $\begin{array}{l}\text { How many contact hours per year does } \\
\text { the shared faculty member teach at your } \\
\text { institution?* }\end{array}$ & 29 (faculty) & $\begin{array}{c}<10 \text { hours }=8 \\
10-20 \text { hours }=10 \\
21-30 \text { hours }=3 \\
31-40 \text { hours }=1 \\
>40 \text { hours }=5 \\
\text { Don't know }=0\end{array}$ \\
\hline $\begin{array}{l}\text { During the past five years, how many courses } \\
\text { has the shared faculty member taught at your } \\
\text { institution?* }\end{array}$ & 29 (faculty) & $\begin{array}{l}\text { One or two }=20 \\
\text { Three or four }=2 \\
\quad>\text { Four }=1 \\
\text { Don't know }=4\end{array}$ \\
\hline
\end{tabular}

How has the shared faculty member taught the $\quad 29$ (faculty) By physically traveling to the secondary institution=26 course or part of a course at your institution?*

Whom does your institution compensate for the shared faculty member's teaching efforts at your institution?*

What is the format of the course(s) taught at your institution by shared faculty member(s)?*
29 (faculty)

Via online or distance education courses=1

Don't know=0

The shared faculty member $=14$

Your institution $=9$

There is no compensation $=1$

Don't know $=0$

29 (faculty)
Traditional didactic $=14$

Small group $=6$

Online $=2$

Combination of the above $=5$

Don't know=2

*Includes only those who answered "Yes" to the first question in this table.

Note: The number of answers to a question might be greater than the $\mathrm{N}$ if more than one answer could be chosen or could be lower than the $\mathrm{N}$ if no answer was given for a faculty member.

these limitations, this study provides a good starting point for further inquiry.

\section{Discussion}

Academic deans were also asked about the advantages and disadvantages of using shared faculty members (Table 3). Academic deans from primary institutions indicated that the use of shared faculty members could be beneficial to their institution by providing service and encouraging inter-institutional collaboration. The shared faculty member could benefit by earning extra income and increasing his or her scholarly activity. These academic deans noted that a negative aspect of having their faculty members teach at another institution would be the time away 
from their institution and a drain on resources in their absence. Respondents from secondary institutions indicated that the use of shared faculty members could be beneficial to the institution because they could have experts in the field teach their students with improved efficiency and less cost. These respondents were concerned about loss of control of curricular content, scheduling, continuity, and student access to the shared faculty member. As highlighted by these comments, students, the shared faculty member, the primary institution, and the secondary institution are all affected by the use of shared faculty members. This section will review potential advantages and disadvantages of using shared faculty members to each of these four stakeholders.

\section{Effect on Students}

Though dental schools are driven by financial pressures and the shortage of faculty members, we should consider the most important factor for deciding whether to use shared faculty members to be the effects on student learning. One potential advantage of using shared faculty members is that those who are nationally recognized experts and outstanding teachers may improve student learning at the secondary institution. ${ }^{22}$ Instead of being taught by faculty members who are teaching outside their area of expertise, shared faculty members could teach topics within their primary area. Being taught by an outstanding teacher will likely improve student learning, as outstanding teachers often use innovative teaching methods to find ways to reach all students.

The use of shared faculty members is conducive to teaching using a modular curriculum format ${ }^{22}$ in which the shared faculty member goes to the secondary institution to teach a module over a few days to weeks. A module may be defined as a unit of instruction that contains learning objectives, assessment methods, recommended resource materials, and expectations for successful completion of the module. ${ }^{27}$ Using modular teaching may be advantageous for students as they can focus on one aspect (anatomy, histology, physiology, etc.) of a subject (e.g., an organ system) instead of taking multiple courses that cover related material but at different times, as in the traditional dental curriculum. Another beneficial byproduct of using shared faculty members to teach using a modular format is that such intense focus on one subject taught by one shared faculty member may encourage faculty members to use less traditional lecturing and to use
Table 3. Survey respondents' comments on advantages and disadvantages to use of shared faculty members (paraphrased and in random order)

Comments from Academic Deans at Primary Institutions

Advantages

- Furthers scholarly activity of faculty member

- Assists with mission of the school by providing service

- Online capability can accomplish objectives without faculty member leaving home institution

- Extra money for faculty member

- Encourages inter-institutional collaboration

- Encourages interdisciplinary education, which serves as role modeling to students

Disadvantages

- Time away from primary institution

- Resource drain

Comments from Academic Deans at Secondary Institutions Advantages

- Shares expertise for schools that don't have it, particularly for areas mandated for accreditation

- Provides for experts in the field (as opposed to non-experts)

- Less cost

- Improved efficiency

- Able to teach a higher quality course than possible using in-house faculty

- Fits modular curricular formats

Disadvantages

- Less control over what they teach and test over

- Shared faculty member is not available to consult with students outside his or her presentation schedule or on the clinic floor, which can make the content less valued by students

- Dependence on shared faculty member's institution

- Dependence on shared faculty member's schedule

- Lack of continuity

- Less responsibility and vested interest on the part of the faculty member

- Inability to update content or buy-in to change format

- Conflicting responsibilities and priorities

more interactive and group learning activities. ${ }^{22}$ The concept of a modular curriculum in predoctoral dental education was proposed a number of years ago to create a more coherent, thematic method of instruction based on the need to organize information. ${ }^{28}$ One concern for use of shared faculty members to teach using a modular format is the potential for lack of integration between modules. However, this issue can be addressed by bringing together regularly all shared faculty members teaching in a course in order to coordinate integration of content across modules. ${ }^{22}$

There is concern in higher education that overreliance on part-time faculty members may 
negatively affect student learning, ${ }^{29}$ and these concerns may be relevant for the use of shared faculty members because they teach "part-time" at the secondary institution. Part-time faculty members spend less time with students outside of class and may have fewer institutional resources and support for their teaching than full-time faculty members. ${ }^{29,30} \mathrm{~A}$ survey of nursing students found that part-time clinical nursing faculty members were rated as less effective than full-time clinical nursing faculty members. ${ }^{31} \mathrm{~A}$ shared faculty member may not be as dedicated to students at the secondary institution as he or she is to students at the primary institution. Also, it may be more difficult for students to interact with the shared faculty member once that individual has returned to the primary institution. One way to address this concern is to have shared faculty members contractually obligated to be available to students after the course is given. ${ }^{22}$ Students can meet with the shared faculty member during the time he or she is teaching at the institution and by e-mail or other electronic means thereafter. Most students and faculty members are likely comfortable communicating using technology.

Though we know of no published studies reporting that the use of shared faculty members enhances student learning, there is anecdotal evidence that this approach has not had a negative impact. At one institution, virtually all of the dental students taught basic science courses by shared faculty members using the modular approach passed the National Board Dental Examination Part I within one year of first taking the exam, with over 90 percent passing on the first attempt. ${ }^{22}$ Except for the first graduating class from this institution, the Part I passing rates were similar to the national passing rates for those years. ${ }^{32}$ Thus, there is potential for but little evidence to support the contention that use of shared faculty will enhance student learning. The dedication of shared faculty members to students at the secondary institutions and the level of support for these faculty members by the secondary institution may be key factors in determining the effect on student learning.

\section{Effect on Faculty Members}

An obvious advantage to shared faculty members is that they will earn income in addition to their salary from their primary institution. Across higher education, the overall purchasing power (i.e., salary adjusted for inflation) has decreased over the last seven years. ${ }^{10}$ This problem is magnified for faculty members who can practice dentistry, as the difference between faculty salaries and dental practice salaries has increased and is projected to reach $\$ 278,000$ for general dentists and $\$ 454,000$ for dental specialists by $2015 .{ }^{4}$ In a recent survey of full-time dental faculty members' perceptions of their work environment, salary was cited most frequently as a negative aspect..$^{33}$ In other surveys, income was one of the most important negative considerations for new dental faculty members when contemplating an academic career, and the satisfaction of new dental faculty members with their institution's efforts to meet their salary needs was poor. ${ }^{34,35}$ Difference in salaries between private dental practice and faculty positions in combination with the debt load carried by recently graduated dentists likely contributes to the shortage of dental faculty members. ${ }^{4,36,37}$ Thus, a recently graduated dentist who becomes a faculty member in a dental school would likely welcome the opportunity to earn income in addition to his or her salary from the primary institution.

More dental school and basic science medical school faculty members are being hired on non-tenure-track appointments. ${ }^{13,15}$ These faculty members have less income stability. Additionally, medical school faculty members who often teach basic science courses to dental students are being hired into tenure-track appointments but often have less of a financial guarantee from their institutions even after they earn tenure. ${ }^{13}$ These factors may also motivate faculty members to seek additional income opportunities by teaching at secondary institutions.

Another potential benefit for shared faculty members is that they may develop collaborative teaching and research opportunities with faculty members at the secondary institution. These collaborations may lead to enhanced learning of students at both institutions and new research funding and publications.

One potential concern for shared faculty members is that they may not have a sense of community and may not have opportunities to participate in curriculum development and faculty governance at the secondary institution. These issues also have been a concern for contingent faculty members in higher education, including health professions education. ${ }^{30,38}$ Contingent faculty members often do not know the policies and procedures of their institution and have to rely on the full-time faculty members for guidance if issues arise. ${ }^{30}$ This is probably true for shared faculty members as well. Another concern is that shared faculty members may not have the support of their primary institutions and thus may not 
be allowed flexibility in their schedule to be able to teach at another institution. Indeed, the most serious challenge for a secondary institution may be to secure the commitment of shared faculty members. ${ }^{22}$

Though contingent faculty members in other areas of higher education may have the same protections of academic freedom as tenured faculty members, renewal of appointments for contingent faculty members may depend more on student evaluations than on the rigorousness of their courses. ${ }^{10}$ Nursing students perceived that tenured faculty members had higher expectations for the quality of the students' work and were more stringent in grading than nontenure-track faculty members. ${ }^{39}$ Thus, dental students might expect that a shared faculty member should be an "easy grader" and give a less favorable evaluation of that faculty member if that is not the case. This could decrease the likelihood that the faculty member would be invited to teach again. In an effort to retain their position at the secondary institution, shared faculty members might be less rigorous in their grading, which could decrease student learning.

Thus, as financial pressures on dental schools increase and the incomes of faculty members stagnate and become less guaranteed by the institution, faculty members might have increased motivation to serve as shared faculty members. Shared faculty members may benefit from increased income but may not have the same sense of community and opportunity to participate in faculty governance at the secondary institution and may face obstacles from their primary institution.

\section{Effect on Primary Institutions}

Institutions make significant investments when hiring faculty members. This investment includes the cost of recruiting, interviewing, and hiring (salary, benefits, and startup) a new faculty member. ${ }^{40}$ Start-up packages for basic scientists may exceed $\$ 500,000 .^{41}$ At institutions of higher education that award doctoral degrees, total compensation (i.e., salary and benefits) averages $\$ 94,600$ for an assistant professor and $\$ 160,775$ for a professor. ${ }^{10}$ Faculty members in the health professions schools are generally compensated more than the average university faculty member. A survey of basic science faculty members at the fifty medical schools receiving the highest amounts of National Institutes of Health funding in 2004 found that the average salary was $\$ 154,974 .{ }^{42}$ According to the ADEA faculty salary report for 2007-08, average total compensation for dental faculty members in the basic sciences was $\$ 110,904$ for an assistant professor and $\$ 192,579$ for a professor. ${ }^{43}$ When basic sciences are taught by dental faculty members, a significant investment must be made in these individuals who may have few student contact hours.

Additional investment is made by the institution by providing dedicated time for research, mentoring, and faculty development, including the development of teaching materials. At some institutions, faculty members retain copyright for the materials they develop as part of their teaching responsibilities. In other institutions, copyright to those teaching materials belongs to the institution. Either way, the secondary institution will benefit when a shared faculty member teaches using materials developed at the primary institution. The concern that shared faculty members use teaching materials developed with support from the primary institution is understandable. However, in higher education, some of the nation's leading institutions (e.g., Stanford University, Yale University, Carnegie Mellon University, and Massachusetts Institute of Technology) are taking steps toward open education by offering free online courses. ${ }^{44,45}$ These and other institutions have found value in sharing teaching materials with learners outside of their programs. Sharing teaching materials with a secondary institution may result in some of the same benefits. For example, the reputation of an institution could be enhanced by allowing its highly skilled educators to teach at other institutions. Shared faculty members could collaborate with educators at the secondary institution, which could lead to improvement of their teaching materials used at the primary institution. Also, a dental student might decide to seek postgraduate education (e.g., specialty training or a Ph.D.) at the primary institution of the shared faculty member.

Thus, the primary institution may be concerned when faculty members use the skills and knowledge gained through the support of the primary institution to teach at a secondary institution without some compensation to the primary institution. An argument may be made that this is no different from the situation in which a faculty member from the medical school teaches in the dental school. However, in that case, the faculty member is an employee of the parent institution, and the resources stay within the parent institution. Still, the secondary institution should compensate the primary institution for its investment in the development of the shared faculty member, or 
the institutions could share faculty members reciprocally to address this concern of inequity.

One approach to addressing the issue of the significant investment in the shared faculty member by the primary institution is for the secondary institution to compensate the primary institution. Our survey of academic deans found that only two of the sixteen who reported there was some compensation for the shared faculty member's teaching indicated that their institution was compensated (Table 1). The other fourteen respondents reported that the shared faculty member alone was compensated for his or her teaching at the secondary institution. Another approach to this issue is for the primary and secondary institutions to enter an agreement in which the institutions share faculty members in both directions. Sharing faculty members and facilities has been proposed as one way to address the financial challenges faced by dental schools. ${ }^{2,3}$

Another potential issue for the primary institution may be scheduling conflicts. Shared faculty members will have to prioritize their commitments to both institutions. Faculty members at some dental schools are given one day per week for private practice or consulting. In our survey, academic deans at the primary institution reported that most shared faculty members use consulting or vacation time when teaching at the secondary institution (Table 1). Thus, the faculty member should work with the primary institution to schedule vacation or consulting time to coincide with the schedule of the secondary institution. If a shared faculty member teaches using distance learning, the primary institution could be negatively impacted if that individual teaches students at the secondary institution during his or her work hours at the primary institution. This could be managed by adhering to rules determined by the primary institution and shared faculty member before initiating teaching for the secondary institution.

One advantage for the primary institution may be that faculty members who are required to take furloughs may be less dissatisfied if they have the opportunity to earn income as a shared faculty member during their furlough period. The primary institution may also benefit from shared faculty members' gaining new teaching approaches that they bring back to their home institution.

It appears that the benefits to the primary institution are outweighed by the investments made to support shared faculty members. However, if shared faculty members are fulfilling their responsibilities to the primary institution by being outstanding teachers, performing scholarly activity, and providing service to the school, then having shared faculty members teach at secondary institutions is not significantly different from a situation in which the faculty members use their consulting time for private practice, vacation, or teaching continuing education courses, in which case the investments made by the primary institution have been fruitful.

\section{Effect on Secondary Institutions}

One of the biggest expenses for dental schools is faculty compensation and benefits. The use of contingent faculty members to teach has been one method of reducing these costs for universities and health professions schools. ${ }^{20}$ Part-time, non-tenuretrack faculty members are generally paid less per hour by the institution than are full-time, tenure-track faculty members. ${ }^{46,47}$ Using shared faculty members to teach in dental schools can also result in significant cost savings. At one institution, the entire basic science curriculum has been delivered for the salary and benefits of two or three full-time equivalent faculty members. ${ }^{22}$ Indeed, the nineteen part-time basic science faculty members from other institutions only account for the equivalent of 0.46 of a full-time faculty member position. In addition to reducing the number of full-time faculty members by using shared faculty, cost to the dental school is decreased because the package of benefits the shared faculty member receives may be significantly reduced. The secondary institution will often pay for the shared faculty member's travel, lodging, food, and honoraria as well as the school's administrative costs. ${ }^{22}$ Some costs are reduced because typically only one shared faculty member is at the secondary institution teaching at any one time so office space and other resources can be minimized. ${ }^{22}$ However, the secondary institution may incur expenses related to frequently searching for, hiring, and providing orientation and training for shared faculty members. This is a major disadvantage of employing contingent faculty across higher education ${ }^{20}$ and is relevant for hiring shared faculty as well. When all of these expenses are considered, dental schools may still anticipate reducing costs by using shared faculty members to teach.

In addition to cost savings, another reason for using shared faculty members is to address the shortage of faculty members in the health professions schools, including dental schools. ${ }^{3}$ The extent of and potential reasons for this faculty shortage were described above. The academic deans reported in our survey that, for a new dental school, the short- 
age of potential full-time faculty members may be the major reason for using shared faculty members. Other academic deans commented that the national pool of qualified faculty members may be small, so that filling vacated positions may be difficult. Thus, a shared faculty member may be hired to fill a short- or long-term need when it is difficult to recruit a fulltime faculty member.

Another advantage for the secondary institution is that it allows the institution to adapt its curriculum in response to innovations in dental education. ${ }^{22}$ In higher education, the use of contingent faculty members allows the institution to bring in experts in emerging fields but not be committed long term to that field if student interest decreases. ${ }^{17}$ In dental schools, this may be less of an issue as the foundational knowledge and skills of dentistry generally change less dramatically.

There are challenges for the secondary institution in using many shared faculty members. In addition to concern with securing commitments from shared faculty members each year, having too few full-time administrators and faculty members increases the risk for burnout due to overwork. ${ }^{22}$ This could exacerbate the current faculty shortage. Also, the level of scholarship at the secondary institution may be reduced if there are fewer faculty members. ${ }^{3}$ Coupled with the shortage of full-time faculty members to supervise students in clinic, ${ }^{6}$ these fewer faculty members will have to spend more time in clinic and have less time to devote to scholarly activity. ${ }^{3}$ Decreasing the level of scholarly activity increases the risk that dentistry may be perceived as a technical trade instead of a learned health profession in the eyes of the public and administrators of research-intensive universities in which many dental schools now reside. A final challenge for the secondary institution may be to engage the shared faculty member so he or she becomes dedicated to the dental school and its students. Part-time faculty members are less likely to participate in faculty governance and may feel less a part of the institution. ${ }^{48}$

Thus, the secondary institution benefits from using shared faculty members by reducing the cost of delivering dental education, addressing shortages of faculty members in specific disciplines, and being more flexible and able to respond to innovative changes in dental education. The challenges to the secondary institution are the risk of burnout of the full-time faculty members, loss of scholarly activity, and the potential for reduced dedication of the shared faculty member to his or her students.

\section{Conclusions}

In summary, financial challenges and the shortage of dental faculty members are among the factors that are driving new approaches to dental education. One such approach is the use of shared faculty members. Our survey of academic deans found that the use of shared faculty members is not rare amongst U.S. and Canadian dental schools, but opinions about this practice are not uniform. The main factor for deciding whether to use shared faculty members should be student learning, for which there are potentially significant advantages. Having nationally recognized experts and outstanding teachers using innovative and effective teaching approaches will enhance student learning.

The use of shared faculty members to teach in dental schools has potential advantages and disadvantages to students, shared faculty members, and primary and secondary institutions. Many of the disadvantages can be addressed by all of these stakeholders' working together to develop collaborative arrangements. Providing the opportunity for secondary institutions to work with primary institutions collaboratively would likely reduce situations in which the secondary institution hires shared faculty members without the consent of the primary institution. Thus, collaborative agreements would reduce the concern that the secondary institution is "stealing" a faculty member from the primary institution. Expectations and compensation could be determined by the shared faculty members and both institutions and include support by the secondary institution for the professional development of shared faculty members and their teaching materials. One approach that could be a model for the dual support of shared faculty members is that used when a faculty member is hired on a joint appointment in two departments within an institution. In that case, the shared faculty member may be paid by both departments and be expected to teach, serve on committees, and participate in faculty governance in both. By having this level of commitment and expectations from both the primary and secondary institutions, the shared faculty member would be more likely to be committed to both institutions, including these institutions' students.

By working together, the primary and secondary institutions can develop creative schedules that allow shared faculty members to teach effectively at both institutions. This would ease the pressure on the shared faculty member and the secondary institution 
of trying to fit their schedules into the primary institution's schedule. Since the primary institution would be receiving compensation for the shared faculty member's teaching at the secondary institution, it may be more flexible and willing to give the shared faculty member time for this endeavor.

Expanding on this collaborative sharing of faculty members, networks could be developed in which multiple institutions coordinate the hiring of faculty members based on what expertise is needed within the network. This expertise would be shared with all of the institutions in the network. It would have to be made clear at the time of hiring that the faculty member would be teaching at multiple institutions. Similarly, primary institutions should be cautious of requiring current faculty members to teach at other institutions. Faculty members who are not enthusiastic about teaching at other institutions would likely not be as effective.

A network of shared expertise may be advantageous to new dental schools as important positions within their faculty may not be filled due to the shortage of dental faculty members. Established dental schools with experienced faculty members may see sharing their faculty with new dental schools as problematic. However, established dental schools could benefit by receiving financial support from the new dental schools. Also, as new dental schools hire more faculty members, collaboration between the two could allow the new school to hire faculty members with expertise in areas in which the established dental school are underdeveloped. Thus, networks of shared faculty members could be beneficial to both new and established schools.

Now is the time for dental education to act. Financial challenges and shortages of dental faculty members are unlikely to be resolved in the near future, and use of shared faculty members is one promising approach to begin to meet these challenges. To take full advantage of the benefits of using shared faculty members, institutions must work together to develop collaborative models. ADEA should support the development of networks of shared expertise by creating a database of interested institutions and content experts and acting as a repository for institutions to share best practices for sharing faculty members. Indeed, the traditional model of dental education in which each institution recreates the entirety of the dental school curriculum locally stands in the way of some innovative possibilities for leveraging resources. ${ }^{2}$ Extending the concept of shared faculty members, groups of faculty members and advanced training equipment could be shared across institutions. Dental schools that are strong in one area could educate students from other dental schools through rotations or distance learning. Creating regional curricula through consortiums of regional education centers would allow dental schools to specialize, share resources, and reduce the cost of educating dental students. ${ }^{2,3}$ For all these reasons, the use of shared faculty members deserves further investigation and discussion.

\section{REFERENCES}

1. Pyle M, Andrieu SC, Chadwick DG, Chmar JE, Cole JR, George MC, et al. The case for change in dental education. J Dent Educ 2006;70(9):921-4.

2. Albino JE. Who will lead dental education in the future? In: Haden NK, Tedesco LA, eds. $75^{\text {th }}$ anniversary summit conference. Washington, DC: American Association of Dental Schools, 1999:1-9.

3. Walker MP, Duley SI, Beach MM, Deem L, Pileggi R, Samet N, et al. Dental education economics: challenges and innovative strategies. J Dent Educ 2008;72(12):14409.

4. Bailit HL, Beazoglou TJ, Formicola AJ, Tedesco LA, Brown LJ, Weaver RG. U.S. state-supported dental schools: financial projections and implications. J Dent Educ 2008;72(2 Suppl):98-109.

5. Bailit HL. The fundamental financial problems of dental education and their impact on education, operations, scholarship, and patient care. J Dent Educ 2008;72(2 Suppl):14-7.

6. Okwuje I, Sisson A, Anderson E, Valachovic RW. Dental school vacant budgeted faculty positions, 2007-08. J Dent Educ 2009;73(12):1415-22.

7. Hebel S. Colleges brace for cuts as state economies take a turn for the worse. Chronicle of Higher Education, January 25, 2008:A17.

8. Jones D; Secretary of Education's Commission on the Future of Higher Education. State shortfalls projected to continue despite economic gains: long-term prospects for higher education no brighter. Washington, DC: U.S. Department of Education, 2006.

9. One faculty serving all students. Washington, DC: Coalition on the Academic Workforce, 2010.

10. Thorton S. It's not over yet: the annual report on the economic status of the profession, 2010-11. Washington, DC: American Association of University Professors, 2011.

11. Rahn DW, Wartman SA. For the health care work force, a critical prognosis. Chronicle of Higher Education, November 2, 2007:B14-5.

12. Fjortoft N, Mai T, Winkler SR. Use of adjunct faculty members in classroom teaching in departments of pharmacy practice. Am J Pharm Educ 2011;75(7):129.

13. Liu M, Mallon WT. Tenure in transition: trends in basic science faculty appointment policies at U.S. medical schools. Acad Med 2004;79(3):205-13.

14. Pilcher ES, Kilpatrick AO, Segars J. An assessment of promotion and tenure requirements at dental schools. J Dent Educ 2009; 73(3):375-82. 
15. 2007-08 survey of dental education: faculty and support staff. Chicago: American Dental Association, 2009.

16. John V, Papageorge M, Jahangiri L, Wheater M, Cappelli D, Frazer R, Sohn W. Recruitment, development, and retention of dental faculty in a changing environment. J Dent Educ 2011;75(1):82-9.

17. Baldwin R, Chronister J. Introduction in teaching without tenure: policies and practices for a new era. Baltimore: Johns Hopkins University Press, 2001:1-12.

18. Haden NK, Beemsterboer PL, Weaver RG, Valachovic RW. Dental school faculty shortages increase: an update on future dental school faculty. J Dent Educ 2000;64(9):657-73.

19. Allan JD, Aldebron J. A systematic assessment of strategies to address the nursing faculty shortage. Nurs Outlook 2008;56(6):286-97.

20. Forbes MO, Hickey MT, White J. Adjunct faculty development: reported needs and innovative solutions. J Prof Nurs 2010;26(2):116-24.

21. Patry RA, Eiland LS. Addressing the shortage of pharmacy faculty and clinicians: the impact of demographic changes. Am J Health Syst Pharm 2007;64(7):773-5.

22. Smith KP, Woldt JL, Cottam WW, Cederberg RA. The Arizona model: a new paradigm for dental schools. J Dent Educ 2011;75(1):3-12.

23. Gubrud-Howe P, Shaver KS, Tanner CA, BennettStillmaker J, Davidson SB, Flaherty-Robb M, et al. A challenge to meet the future: nursing education in Oregon, 2010. J Nurs Educ 2003;42(4):163-7.

24. Tanner CA, Gubrud-Howe P, Shores L. The Oregon Consortium for Nursing Education: a response to the nursing shortage. Policy Polit Nurs Pract 2008;9(3):203-9.

25. Kimball HR, Young PR. Educational resource sharing and collaborative training in family practice and internal medicine: a statement from the American Boards of Internal Medicine and Family Practice. JAMA 1995;273(4):320-2.

26. Schell EE, Stock PL, eds. Moving a mountain: transforming the role of contingent faculty in composition studies and higher education. Urbana, IL: National Council of Teachers of English, 2001.

27. Manogue M, McLoughlin J, Christersson C, Delap E, Lindh C, Schoonheim-Klein M, Plasschaert A. Curriculum structure, content, learning, and assessment in European undergraduate dental education: update 2010. Eur J Dent Educ 2011;15(3):133-41.

28. King AD, Allen DL, Mackenzie RS, Medina JE. A modular curriculum design for dentistry. J Dent Educ 1972;36(6):20-3.

29. Benjamin E. How overreliance on contingent appointments diminishes faculty involvement in student learning. Peer Rev 2002;4-10.

30. Umbach PD. How effective are they? Exploring the impact of contingent faculty on undergraduate education. Rev Higher Educ 2007;30(2):91-123.

31. Allison-Jones LL, Hirt JB. Comparing the teaching effectiveness of part-time and full-time clinical nurse faculty. Nurs Educ Perspect 2004;25(5):238-43.
32. Tsai TH. Update on the National Board Dental Examinations: research and development/psychometrics. Presentation at American Dental Education Association Annual Session \& Exhibition, San Diego, CA, March 2011.

33. Froeschle ML, Sinkford JC. Full-time dental faculty perceptions of satisfaction with the academic work environment. J Dent Educ 2009;73(10):1153-70.

34. Shepherd KR, Nihill P, Botto RW, McCarthy MW. Factors influencing pursuit and satisfaction of academic dentistry careers: perceptions of new dental educators. J Dent Educ 2001;65(9):841-8.

35. Schenkein HA, Best AM. Factors considered by new faculty in their decision to choose careers in academic dentistry. J Dent Educ 2001;65(9):832-40.

36. Chmar JE, Harlow AH, Weaver RG, Valachovic RW. Annual ADEA survey of dental school seniors, 2006 graduating class. J Dent Educ 2007;71(9):1228-53.

37. Financing dental education: public policy interests, issues, and strategic considerations. Washington, DC: U.S. Department of Health and Human Services, Health Resources and Services Administration, 2005.

38. Finn T, King J, Thorburn J. The educational needs of parttime clinical facilitators. Contemp Nurse 2000;9(2):132-9.

39. Salamonson Y, Halcomb EJ, Andrew S, Peters K, Jackson D. A comparative study of assessment grading and nursing students' perceptions of quality in sessional and tenured teachers. J Nurs Scholarsh 2010;42(4):423-9.

40. Schloss EP, Flanagan DM, Culler CL, Wright AL. Some hidden costs of faculty turnover in clinical departments in one academic medical center. Acad Med 2009;84(1):32-6.

41. Roe D. Recruitment packages for starting faculty. Washington, DC: Association of American Medical Colleges. At: www.aamc.org/download/77486/data/recruitment pkgs.pdf. Accessed: December 7, 2011.

42. DesRoches CM, Zinner DE, Rao SR, Iezzoni LI, Campbell EG. Activities, productivity, and compensation of men and women in the life sciences. Acad Med 2010;85(4):631-9.

43. ADEA faculty salary report, 2007-08. Washington, DC: American Dental Education Association, 2010.

44. Rice A. Learn about robots from Stanford professors, free of charge. Chronicle of Higher Education, November 19 , 2011.

45. Parry M. MIT will offer certificates to outside students in online courses. Chronicle of Higher Education, January $1,2012$.

46. Monks J. The relative earnings of contingent faculty in higher education. J Labor Res 2007;28:487-501.

47. Bettinger E, Long BT. Do college instructors matter? The effects of adjuncts and graduate assistants on students' interest and success. Cambridge, MA: National Bureau of Economic Research, 2004.

48. Banachowski G. Perspectives and perceptions: the use of part-time faculty in community colleges. Community Coll Rev 1996;24(2):49-62. 